\title{
Design and Development of a PBL Mobile Application in Islamic Education: A Conceptual Framework
}

\author{
Gamal Abdul Nasir Zakaria and Aliff Nawi
}

\begin{abstract}
This article aims to design and develop a Problem Based Learning (PBL) Mobile Application for teaching and learning in Islamic Education at the Polytechnic Brunei Darussalam. The development methodology-based application that divides the ADDIE model of instructional development activities into five phases: Analysis, Design, Development, Implementation and Evaluation. Each phase is explained in detail to bring out what action is taken on each phase. ADDIE model has listed guidelines that should be implemented detailed and systematically which involves analysis, design, development, implementation and evaluation. The priority aspects such as the content, learning theory and learning strategies are taken into account in analysing and designing. The researchers applied the behaviorism and constructivist theory as the learning theory. While PBL strategies are embedded in the application throughout the designing and development phase. Development process of an effective mobile application is not easy or takes shorter time but, it requires detailed and systematic planning. A model conceptual framework is constructed to help researchers to make the action more regular. At the end of the study, the authors present each element of the conceptual framework for the design and development a mobile application in teaching and learning in Islamic Education.
\end{abstract}

Index Terms - Design, development, mobile application, PBL, Islamic education, conceptual framework.

\section{INTRODUCTION}

Discussions on a new approach to Islamic Study started actively since "The First Conference on Muslim Education" held in Makkah in 1977 [1]. Due to the high level of awareness on the importance of Islamic Education throughout the world, therefore conferences were held several times to bring Islamic thinkers together to discuss issues on Islamic Education world. Different conferences were held at different times, eg. in Islamabad (1980), Dakka (1981), Jakarta (1982), Kaherah (1982) and Amman (1990) [2]. Since then, effort has been made by Islamic countries to design and implement Islamic Education and its philosophy in accordance with the 21 st century demands and challenges.

Moreover, the Islamic Educational Philosophy emphasizes the development of attitudes, skills, personality and view on life that is aligned with the knowledge, skills and appreciation to the Al-Quran and As-Sunnah. The process of producing a balanced man from the combination of National

Manuscript received September July 2, 2019; revised November 12, 2019.

Gamal Abdul Nasir Zakaria is with the Sultan Hassanal Bolkiah Institute of Education (SHBIE), Universiti Brunei Darussalam, Brunei (e-mail: gamal.zakaria@ubd.edu.bn).

Aliff Nawi is with the School of Education, Universiti Utara Malaysia, Malaysia (corresponding author; e-mail: aliffnawi@yahoo.com).
Education Philosophy and Philosophy of Islamic Education covers various aspects of human life. Among them is the application education in oneself in order to create a personality and worldview consistent with human attribute as the representative of Allah [3]. This holistic education implementation will produce individuals who are responsible and trust in themselves as well as abstain from various bad elements. As the perfection of education received, Prophet said [4]: ذأدي بـ بي ف أحدن رب ي أدب ني Meaning: My God educate me and makes the best of the best education. The hadith shows that education is an important aspect in human life. Perfect implementation of education will produce balanced individuals intellectually, emotionally, spiritually and physically. Islam concerns aspect of education and perfect knowledge mastery. This is because education is one of the main pillars of a country's social development. Neglecting education means disregard of society's welfare and affects the development of a country.

\section{TEACHING AND LEARNING IN ISLAMIC EDUCATION}

In the context of teaching and learning, teachers particularly, are 'role model' that play major role in implementing Islamic values in the life of the students [5]. Obviously, the values of Islam should be nurtured and implemented into every subject, especially in Islamic education. Implementation of good practice and effective teaching would help students in improving their knowledge and appreciation of religious values [6]. However, researches on good practice teaching of Islamic education teacher has not yet achieve satisfaction level [7], [8]. Meanwhile, teaching method use by teachers are still questioned its' effectiveness. Previous research shows that teachers always used teacher-centered approach in the classroom [9]. This method is often used in teaching and learning because it is easier, does not need longer preparation or incurred any cost [10]. Moreover, the usages and selection of this method is due to the teacher themselves whom have experience in teaching and education using the same method [11]. Therefore, it makes teachers to apply this method without needs to think about other method during the teaching and learning implementation process at school. Besides that, issues on teacher's work load also gives negative impact on teaching and learning in school. According to Shaari et al. [12], teachers are burdened with many tasks including clerical, facilitator, motivator, planners, curriculum advisers, chairman of clubs, associations uniformed unit, sport coaches and teacher data. This will affect quality of teaching and learning. Especially research by Ali [13] showed that lack of time faced by teachers gives negative effects on teaching 
preparation including making reference in order to improve master in their respective fields. From the aspect of teaching aids usage, difficulties to get references in websites or Islamic education portal is a limitation for teachers. Research done by Hamzah [14] and Nawi and Gamal [15] shows that most teaching aids provided are very general and does not help teachers to teach Islamic Education base on prescribe syllabus. However, Norhatimah and Ab Halim [16] have listed 158 suitable websites to be use for the Islamic Education. Yet, most of the websites are not functioning well and just show information only without anything concerning values implementation on users. Therefore, based on the above problems described, this research will design and develop mobile application for teachers and students in Islamic Education course at Polytechnic Brunei Darussalam. This proposal is to give alternative for the user on different teaching and learning methods besides than applying values indirectly.

\section{Design And DeVelopment of Mobile AppliCATION}

In the process of producing the mobile application, development designation should be given attention because it is the crucial part or the back bone in this research. The development methodology is a framework that uses information systems as a guide for the researcher in software development. Instructional design for the framework concept adapt from ADDIE Model [17] consist of five phases starts from analyses phase, design, followed by development and implementation as well as evaluation. Instructional design component in developing this mobile application involves phases that shows methods or steps that needed to follow in the whole process of implementation, development and evaluation. ADDIE model was chosen to develop mobile application because of the model design that stress on repetition at each phase. Each phase is intertwined with one and another. If the phase cannot be executed properly, this process can be repeated until check completed. This is important in achieving the objective of mobile application design and to avoid technical mistakes during the process.

\section{A. Phase 1: Needs Analysis}

Analyses needs phase is a crucial phase in material development process. This phase will determine input selection which is the core in this mobile application development. Nor Azah et al. [18] stated that analysis phase starts with idea, objective and identifying respective user. Therefore, this needs analysis is divided into three stages. At the first stage, researcher will identify its target group and mobile application development needs through questionnaire that is adapt from Nawi et al. [19] and interview questions design by the researcher. Target group that will use this mobile application is Polytechnic student who are new students of first semester.

In the second stage, research will identify some experts in Islamic Education field to solicit views on the content needs in this mobile application. Moreover, opinions of some experts from Technology fields will also be taken into account. This phase is important for the design of develop mobile application content meets research objective. This needs specification will help researcher to identify mobile application development to be implemented well and systematic according to the guidelines that have been set as in the figure below.

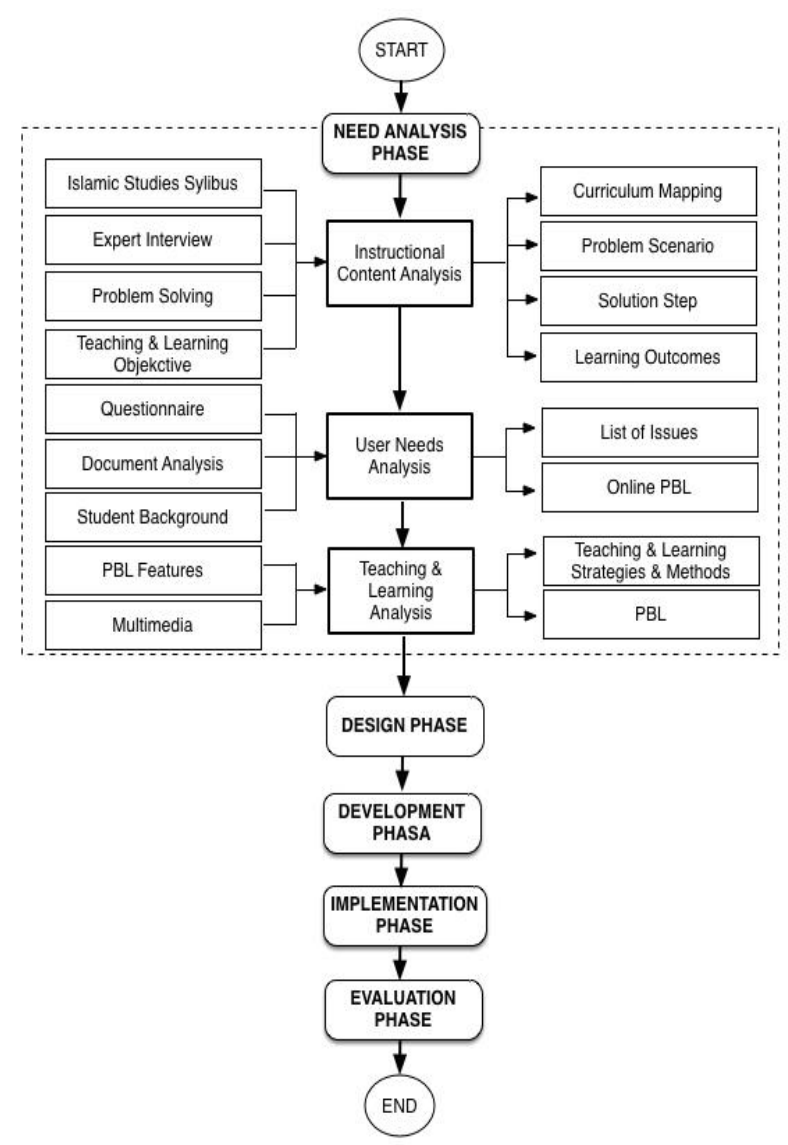

Fig. 1. Need analysis phase.

\section{B. Phase 2: Design}

Once analysis phase done implement, the next phase is design phase. This level itemizes types of task needed to be implement so that design meet its learning objectives. Media selection such as video, text, images and material support based on teaching strategies will also stressed on this design phase. According to Nor Azah et al. [18], design phase is the phase that determines each multimedia element even its content so that it meets research objective before adding it into the storyboard. Added multimedia includes video, picture, audio and texts.

Main activities in this design phase were carried out with regard to the constructivist learning theory and behaviorism, while the structural approach is discovery learning strategy. The design of mobile application content is well adapted to the needs of teachers and students to become learning organizations systematically and in accordance with the proper content. After that, other design will be built by including the outlined items in this mobile application.

\section{Phase 3: Development}

Development phase involves restructuring content program, organization chart, storyboard, flowchart program, screen design, and evaluation process and repetition. This phase is the results of specified activities in phase 1 and phase 2 of the mobile application so that it is easier to understand. 
Develop mobile application is based on information of the analysis phase and design phase. Views and inputs of experts applied to clarify the validity of develop. Before the mobile application is used, the researcher will carry out a technical test on the developed mobile application. This technical test involves only five people who have similar characteristic to the actual group used in the research. Nielson [20] have underlined the usage of five people respondent is enough on preliminary analysis for a researcher to identify problems in the usability of mobile application. Next, heuristic study will be conducted which involves expert group. Heuristic research is the final research to identify the usability of a mobile application in the final stages of development. Then, an improvement is done, and draft mobile application were provided based on suggestions and feedback from the experts' verification.

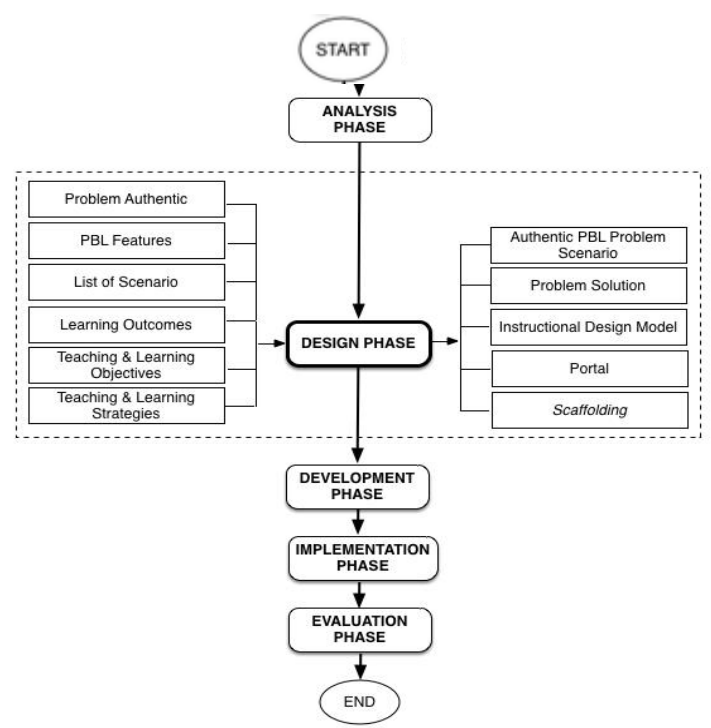

Fig. 2. Need analysis phase.

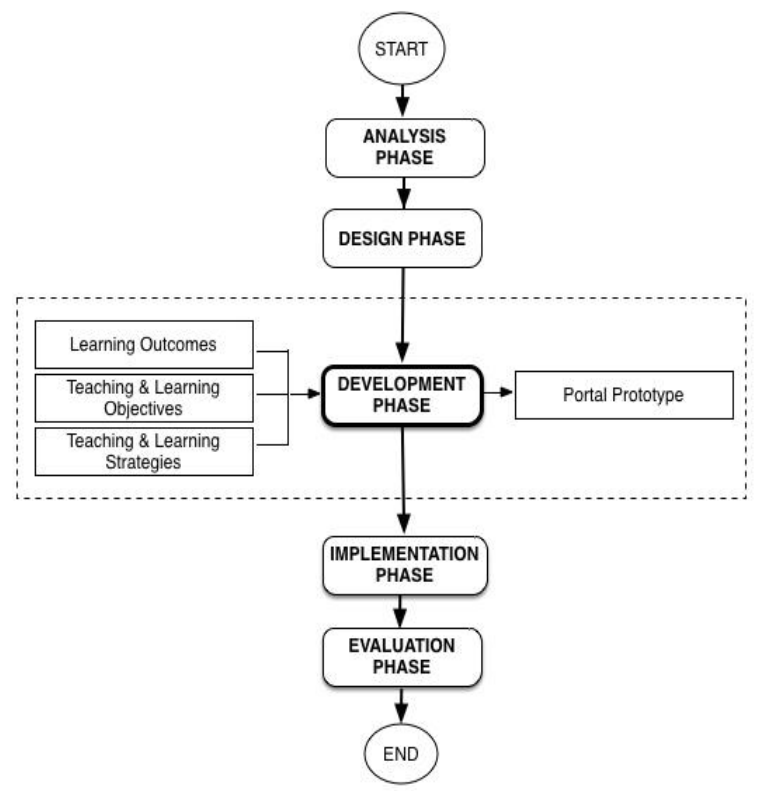

Fig. 3. Development phase.

\section{Phase 4: Implementation}

The implementation phase is the phase whereby the mobile application is used by users or respondents. In this phase, the developed mobile application was ready, have high usability and technical problems free. Before mobile application is fully utilized by the actual group, researcher will conduct pilot study on a group of students to identify problems that arise in the developed mobile application.

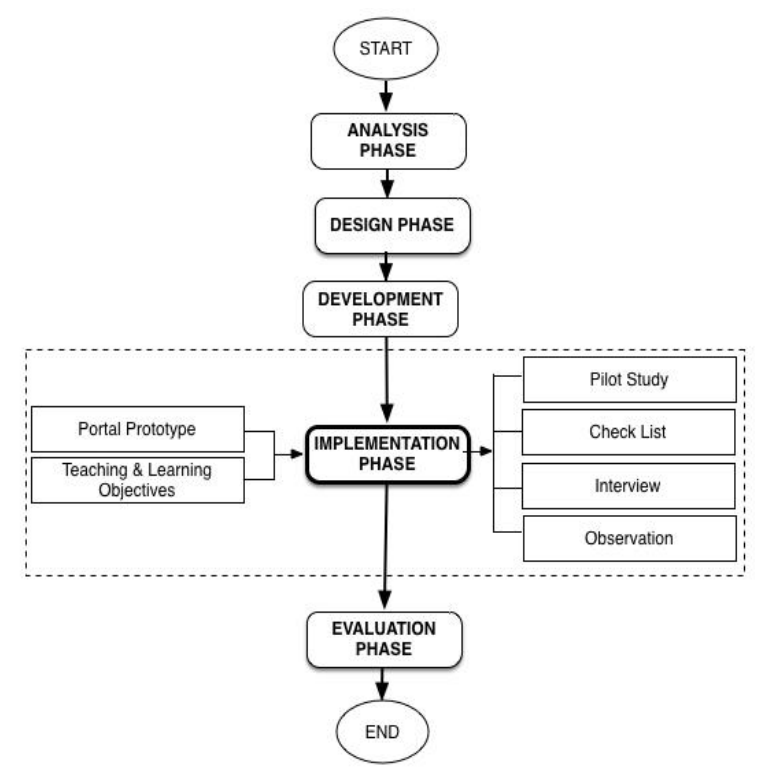

Fig. 4. Implementation phase.

\section{E. Phase 5: Evaluation}

Evaluation phase is the final phase in the ADDIE instructional model. This phase aims to obtain comments, criticisms and feedback from users. Feedback can be used to improve the quality of the mobile application and meet the user's wants and needs. ADDIE emphasizes the concept that the training program requires planning, review and revision. At each phase of the ADDIE model provides a checkpoint that allows experts and users to evaluate the progress of implemented material construction. Repaired mobile application in the implementation phase will be judged on usability aspects. Types of assessment is divided into two which is formative assessment and summative assessment.

Formative assessment is a process that is carried out by stages based on the requirements related to the current phase of development [21]. Developed software will be evaluated in a learning environment that best approximate the true actual learning conditions. Evaluation stage are also known as trial field [22]. Formative evaluation of the mobile application will be evaluated by four experts of content aspect and three experts of technical aspects. This evaluation will be carried out by a set of questionnaires to provide an evaluation of the relevant aspects.

While summative evaluation is conducted to ensure that the mobile application achieve its objectives. According to Harun et al. [22] summative assessment generally consists of two phases, which is the first phase of expert's evaluation and evaluation of specialist field. Content analysis, design and suitability were also conducted at expert evaluation phase. Summative evaluation is complemented by field evaluation phase. Through field-based analysis, the advantages and disadvantages of the mobile application is identified to ensure the development can achieve its objectives. This evaluation will be conducted in two classes of around 28 students in each class who take courses in Islamic Education 
at Polytechnic. Evaluation will be seen from the aspect of mobile application usability including design aspect, technical aspects of user friendliness and user satisfaction. Other than that, observations were also carried out and recorded to identify the element values that occur during the process of teaching and learning.

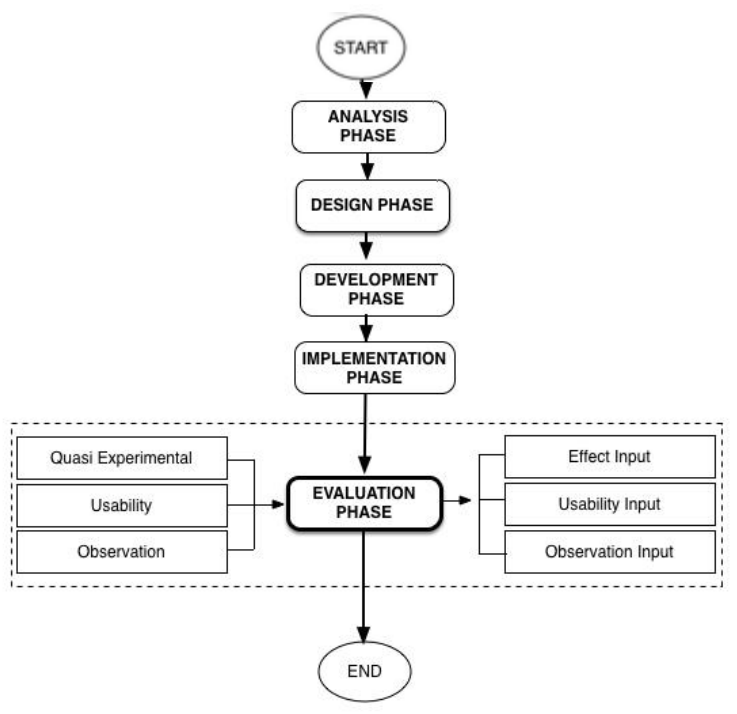

Fig. 5. Evaluation phase.

\section{RESEARCH CONCEPTUAL FRAMEWORK MODEL}

In creating a mobile application, various aspects need to give attention. ADDIE model has listed guidelines that should be implemented detailed and systematically which involves analysis, design, development, implementation and evaluation. Development process of an effective mobile application is not easy or takes shorter time but, it requires detailed and systematic planning. This is important so that the mobile application is at the highest standards of quality as expected. Apart from applying instructional design model, this study also applies some theories. Some of the learning theory applied are behavirism theory and constructivism theory. While learning strategy that were used is problem-based learning approach. Figure below shows the conceptual framework of research design and construction mobile application for teaching and learning Islamic Education at Polytechnic.

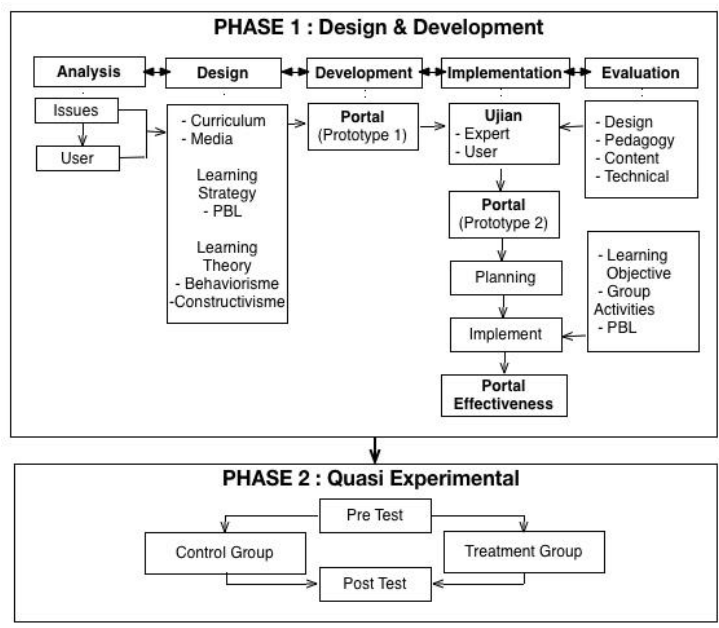

Fig. 6. Conceptual framework.
Besides than usability evaluation, researcher have chosen to implement in the form of quasi-experimental study was conducted to see to what extent PBL Mobile application can foster Islamic values in students. Through this method, the two groups (control group and the treatment group) will take the test (psychometric inventory value) the same at the beginning of the semester and end of semester. Results achievement of results will be compared to see whether there is an increase in value that occurred.

\section{CONCLUSION AND RECOMMENDATION}

This research involves three main aspects, which are the development of the mobile application, usability evaluation and evaluation of Islamic values among the student. The mobile application is developed to provide different teaching and learning approach in Islamic Education at Polytechnic. Apart from implementing different teaching and learning approach through PBL, the study also focuses on the implementation and nurturing Islamic values in students. Implementation and nurturing Islamic values are important to produce students who are able to appreciate Islam not only from the aspect of understanding even but also in aspects of practice and religious. Conjunction of this awareness, researcher thinks there is a need to conduct research in giving new impetus to the teaching and learning of Islam. It is hoped that this study can contribute to various parties, especially those involved in education, especially in Islamic Education.

\section{CONFLICT OF INTEREST}

The authors declare no conflict of interest.

\section{AUTHOR CONTRIBUTIONS}

Zakaria, GAN and Nawi, A conceived and designed the study. Zakaria and Nawi performed the project and wrote the paper; all authors had approved the final version.

\section{ACKNOWLEDGMENT}

We would like to express our sincere gratitude and special thanks to everyone who has supported and made this paper possible. We would like to extend our acknowledgment of gratitude toward the significant contributors. Special thanks to Graduate Research Scholarship (GRS) by Universiti Brunei Darussalam for supporting the research. We would like to thank Pg Dr Norkhairiah Pg Hashim and Dr Hjh Salwa DSS Mahalle, for most support and encouragement. We would also like to thank to students from Politeknik Brunei Darussalam for their participation in this research. Finally, we sincerely thank to our parents, family, and friends, who provide the advice and support. The product of this paper would not be possible without all of their support and encouragement.

\section{REFERENCES}

[1] S. A. Ashraf, "Faith-based education: A theoretical shift from the secular to the transcendent," Muslim Education Quarterly, vol. 11, no. 2, pp. 1-4, 1994.

[2] W. M. N. W. Daud, Filsafat dan Praktik Pendidikan Islam Syed M. Naquib Al-Attas, Bandung Indonesia: Pustaka Mizan, 2003. 
[3] S. N. Al-Attas, Aim and objective of Islamic Education, London: Hodder \& Stoughton, 1979.

[4] Ibnu Sam'ani, Kitab Adab al-Imla' wa al-Istimla', Beirut: Dar al-Kitab al- A 'rab, n.d.

[5] M. K. Othman and A. Suhid, "Peranan Sekolah dan Guru dalam Pembangunan Nilai Pelajar Melalui Penerapan Nilai Murni: Satu Sorotan," Journal of General Studies, vol. 11, pp. 117-130, 2010.

[6] A. R. A. Rashid, Pendidikan nilai merentasi kurikulum, Kuala Lumpur: Dewan Bahasa \& Pustaka, 1993.

[7] M. A. M. Nawi, E. A. Jamsari, M. I. Hamzah, and A. Umar, "The impact of globalization on current Islamic education," Australian Journal of Basic and Applied Science, vol. 6, no. 8, pp. 74-78, 2012.

[8] A. Nawi, M. I. Hamzah, and A. A. Abdul-Rahim, "Teachers acceptance of mobile learning for teaching and learning in Islamic education: A preliminary study," The Turkish Online Journal of Distance Education, vol. 16, no. 1, pp. 184-192, 2015.

[9] M. A. M. Nawi and Y. Ramlan, "A study on the strategies and practice of teaching among trainee teachers during teaching training," The Online Journal of Islamic Education, vol. 2, no. 1, pp. 1-6, 2014.

[10] A. Nawi, M. I. Hamzah, C. C. Ren, and A. H. Tamuri, "Adoption of mobile technology for teaching preparation in improving teaching quality of teachers," International Journal of Instruction, vol. 8, no. 2 , pp. 113-124, 2015.

[11] A. H. Tamuri, K. A. Razak, and S. Awaluddin, "Kaedah pengajaran pendidikan Islam: Konvensional dan inovasi," Kaedah $P \& P$ Pendidikan Islam, Bangi: Universiti Kebangsaan Malaysia Press, 2010, pp. 38-70.

[12] A. S. Shaari, A. R. Romle, and M. Z. Kerya, "Beban Tugas Guru Sekolah Rendah. Kertas Kerja Seminar Kebangsaan Kepimpinan dan Pengurusan Sekolah," Anjuran Universiti Utara Malaysia, pp. 12-14, 2006.

[13] R. M. D. R. Ali. "Faktor-faktor yang mendorong tekanan kerja (stres) dalam kalangan guru-guru sekolah menengah pasir puteh," Tesis Sarjana, Fakulti Pendidikan dan Bahasa, Universiti Terbuka Malaysia, 2011.

[14] M. I. Hamzah. "The impact of educational change in Malaysian Smart Schools on Islamic education teachers and students," $\mathrm{PhD}$ thesis, University of Warwick, 2007.

[15] A. Nawi and G. A. N. Zakaria, "Development and evaluation of IPBL portal in brunei polytechnic," Jurnal Komunikasi, Malaysian Journal of Communication, vol. 32, no. 1, pp. 261-285, 2016.

[16] Norhatimah and A. H. Tamuri, "Pengajaran dan Pembelajaran Pendidikan Islam Berasaskan Web," Kaedah P\&P Pendidikan Islam, Bangi: Universiti Kebangsaan Malaysia Press, 2010.

[17] R. M. Gagne et al., Principles of Instructional Design, $5^{\text {th }}$ Ed. Belmont, California: Thomson Wadsworth Learning, 2005.

[18] N. A. A. Aziz, S. Samsudin, A. Alias, F. M. Razali, Z. Zakaria L. A. A Rifaie, K. Ramli, and N. F. A. Wahab. "Implementing multimedia and simulation in developing computerized blood circulation and bodily movement during obligatory prayers (SolatSim)," in Proc. Regional Conference on Knowledge Integration in ICT, 2010, pp. 735-738.

[19] M. A. M. Nawi, E. A. Jamsari, A. Sulaiman, and M. I. Hamzah, "Development and evaluation of ning social network for teaching training online surveillance," Turkish Online Journal of Distance Education, vol. 14, no. 1, pp. 245-255, 2013.

[20] J. Nielsen, Why You Only Need to Test with 5 Users, 2000.

[21] S. M. Alessi and S. R. Trollip, Multimedia for Learning: Methods and Development, New Jersey: Prentice Hall, 2001.

[22] J. Harun, B. Aris, and Z. Tasir. Pembangunan Perisian Multimedia: Satu Pendekatan Sistematik, Kuala Lumpur: Venton Publishing, 2001.

Copyright $\odot 2020$ by the authors. This is an open access article distributed under the Creative Commons Attribution License which permits unrestricted use, distribution, and reproduction in any medium, provided the original work is properly cited (CC BY 4.0).

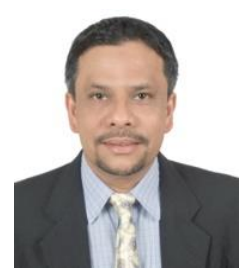

Gamal Abdul Nasir Zakaria is an associate professor in Sultan Hassanal Bolkiah Institute of Education (SHBIE), Universiti Brunei Darussalam. He graduated from Institut Agama Islam Negeri (IAIN), Sultan Syarif Qasim, RIAU (Teaching Arabic Language and Islamic Education), International Islamic University Malaysia (IIUM) (master in teaching Arabic to Non Arabic Speakers and Islamic Education), \& the Ph.D in education (Islamic Education), Universiti Kebangsaan Malaysia (UKM). He teaches various subjects including teaching methods, philosophy, analysis critical of Islamic education, method of teaching Arabic to Non-Arabic speakers and Islamic jurisprudence. He also supervises research students of masters and doctoral programmes. His research interest is methods in teaching Arabic \& Islamic education, history and philosophy of Islamic education and innovation and development of Islamic education curriculum.

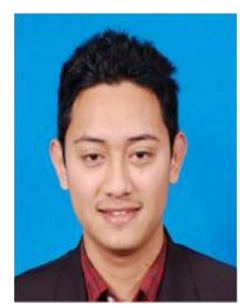

Aliff Nawi is a senior assistant professor in School of Education, Universiti Utara Malaysia (UUM, Malaysia). He graduated from Universiti Kebangsaan Malaysia (B.Ed. \& M.Ed. in Islamic education) and Universiti Brunei Darussalam (Ph.D in education). He teaches various subjects including teaching methods, ethics \& moral education, instructional leadership in education, \& management of Islamic education. He also supervises research students of masters and doctoral programmes. His current research is on digital ethics, Islamic values and educational technology. 